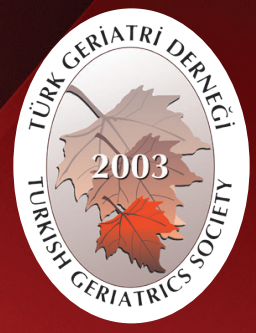

Turkish Journal of Geriatrics

DOI: $10.31086 /$ tjgeri.2018240417

2018;21 (2):166-172

- Songül ÖZYURT ${ }^{1}$

- Aziz GÜMÜŞ²

- Bilge YILMAZ KARA

- Dilek KARADOĞAN ${ }^{1}$

- Neslihan ÖZÇELIK ${ }^{3}$

- Melek MEMOĞLU1

- Ünal ŞAHIN ${ }^{1}$

\title{
CHANGING CLINICAL CHARACTERISTICS OF PULMONARY THROMBOEMBOLISM IN THE ELDERLY
}

\section{Abstract}

Introduction: This study aims to examine the clinical differences between the Pulmonary Thromboembolism patients aged 65 and above and younger patients attending the clinic of chest diseases.

Materials and Method: The study sample included the patients diagnosed with Pulmonary Thromboembolism at the Chest Diseases Clinic of Recep Tayyip Erdoğan University Faculty of Medicine between June 2016 and December 2017. Patients' files were scanned retrospectively and the participants were divided into two groups: elderly patients aged 65 and over (elder) and patients under 65 years of age (younger). These two groups were compared in terms of clinical, laboratory and radiological characteristics of Pulmonary Thromboembolism.

Results: A total of 149 patients consisting of $90(60 \%)$ female and $59(40 \%)$ male patients with an average age of $73 \pm 13$ years (22-94) were included in the study. The most common symptom was dyspnea and the most frequently observed risk factor was immobility. The prevalence of chest pain was significantly higher in the patients younger group than elder group. Besides, no change in consciousness was observed in the patients in younger group, while altered state of consciousness was observed in 17 (15\%) of 113 patients in elder group.

Conclusion: Especially in patients elder, chest pain loses its significance, while unexpected symptoms such as altered state of consciousness can be observed. This should be taken into account; otherwise it may result in a delay in diagnosis.

Keywords: Pulmonary embolism; Diagnosis; Aged; Symptom assessment

ARAŞTIRMA

CORRESPONDANCE

Songül ÖZYURT

Recep Tayyip Erdoğan University, Faculty of Medicine, Department of Chest Diseases,

Rize, Turkey

Phone: 4642170369

e-mail: drsongul@gmail.com

Received: 28/02/2018

Accepted: $25 / 04 / 2018$

Recep Tayyip Erdoğan University,

Faculty of Medicine, Department of Chest

Diseases, Rize, Turkey

2 Kumluca Medicus Hospital, Chest Diseases,

Rize, Turkey

${ }^{3}$ Kaçkar State Hospital, Chest Disease Clinic,

Rize, Turkey
YAŞLI HASTALARDA

PULMONERTROMBOEMBOLININ DEĞIŞEN KLINIK KARAKTERLERI

\section{$\ddot{O}_{z}$}

Giriş: Çalışmamızın amacı, kliniğimizde takip edilen Pulmoner tromboemboli hastalarında 65 yaş ve üstü yaşlı hastaların daha genç hastalara göre klinik farklııklarını araştırmaktır.

Gereç ve Yöntem: Çalışmaya Recep Tayyip Erdoğan Üniversitesi Tıp Fakültesi Göğüs Hastalıkları kliniğinde Haziran 2016- Aralık 2017 tarihleri arasında Pulmoner tromboemboli tanısı ile takip edilen hastalar alındı. Hastaların dosyaları retrospektif olarak taranarak 65 yaş ve üstü yaşlı hastalar (yaşlı) ve 65 yaş altı hastalar (genç) olmak üzere olarak iki gruba ayrıldı. Bu iki grup; klinik, laboratuar, radyolojik özellikleri açısından karşılaştırıldı.

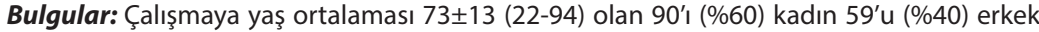
olmak üzere toplam 149 hasta alındı. Hastalarda en sık saptanan semptom nefes darlığı, en sık tesbit edilen risk faktörü immobilite idi. Yaşlı grupta göğüs ağrısı genç gruba göre anlamlı olarak düşüktü ( $p=0.004)$. Ayrıca genç hastalarda bilinç değişikliği olmazken, yaşlı 113 hastanın 17 'sinde (\%15) bilinç değişikliği semptomu vardı ( $p=0.013$ ).

Sonuç: Özellikle yaşlı hastalarda göğüs ağrısı önemini yitirmekte ve bilinç değişikliği gibi pulmoner tromboembolide beklenmedik bulgular görülebilmektedir. Bu durum tanıda gecikmeye neden olabileceğinden akılda bulundurulmalıdır

Anahtar sözcükler: Pulmoner embolizm; Tanı; Yaşlı; Semptom değerlendirme 


\section{INTRODUCTION}

Pulmonary Thromboembolism (PTE) is a common clinical entity whose incidence increases along with age. Its annual incidence increases dramatically especially over 70 years of age, rising up to $1 \%(1)$. It has high mortality. It is one of the most important causes of hospital mortality (2). Short-term mortality rate is higher in the elderly compared to the younger patients (3). Hereditary or acquired risk factors play an important role in the disease etiology. However, the reason behind the disease cannot be found in $20 \%$ of cases.

The most common symptom of PTE is dyspnea and the most common sign is tachypnea. Pleuritic chest pain is prominent in more than half of the cases (4). However, clinical symptoms and sings are non-specific. This makes it difficult to establish an accurate diagnosis. Cardiopulmonary diseases which have similar signs and symptoms with PTE are commonly observed in elderly patients, making it more difficult to establish a diagnosis in clinical presentation. Moreover, d-dimer and ventilation perfusion scintigraphy, which are the tests helping to diagnose embolism, have lower diagnostic value in the elderly $(5,6)$. This causes delayed diagnosis and increased mortality in the elderly patients.

This study aims to examine the clinical differences between the patients elder and younger patients diagnosed with pulmonary embolism by performing spiral CT scans of the thorax.

\section{MATERIALS AND METHOD}

The study was conducted at the Chest Diseases clinic of Recep Tayyip Erdoğan University Faculty of Medicine. The study sample included the patients hospitalized at the chest diseases clinic due to pulmonary thromboembolism between 01.06.2016-01.12.2017. Patients' files were scanned retrospectively and data was collected. Diagnosis of pulmonary embolism is established in all patients by performing contrast-enhanced spiral CT scans of the thorax (BTPA). Color Doppler ultrasound imaging of lower extremity was performed for the detection of deep vein thrombosis (DVT). Echocardiographic examination was performed for the diagnosis of right ventricular dysfunction. D-dimer and troponin-T testing and arterial blood gas, hemogram and biochemical analyses were performed on all patients. The participants were divided into two groups: elderly patients aged 65 and over (elderly group) and patients under 65 years of age (younger group). These two groups were compared in terms of clinical, laboratory and radiological characteristics of PTE. Besides, 30-day mortality rates were estimated and compared.

\section{Statistical analysis}

Statistical analysis was performed using SPSS (SPSS version 16; SPSS Inc., Chicago, IL, USA). Continuous variables were presented as mean \pm sd and categorical variables were presented as percentages. Chi-square test was used to compare the ratios. The Student's t-test was used to compare the means of parametric variables. $\mathrm{P}<0.05$ was considered statistically significant.

\section{RESULTS}

A total of 149 patients consisting of 90 (60\%) female and 59 (40\%) male patients with an average age of $73 \pm 13$ years (22-94) were included in the study. The patients were divided into two groups as the elderly and younger. Table 1 shows the comparison of such parameters as demographic characteristics, clinical characteristics and arterial blood gas characteristics. 
Table 1. Comparison of patients younger group (Age $<65$ ) and elder group (Age $\geq 65$ ).

\begin{tabular}{|c|c|c|c|}
\hline & Younger group $(n=36)$ & $\begin{array}{l}\text { Elder group } \\
\qquad(n=113)\end{array}$ & $\mathrm{p}$ \\
\hline Age (year) & $54 \pm 9$ & $79 \pm 7$ & $<0.001$ \\
\hline $\operatorname{Sex}(M / F)$ & $22 / 14$ & $37 / 76$ & 0.002 \\
\hline Pulse (/min) & $99 \pm 19$ & $101 \pm 17$ & 0.532 \\
\hline Systolic BP (mmHg) & $114 \pm 27$ & $115 \pm 23$ & 0.849 \\
\hline Diastolic BP (mmHg) & $69 \pm 10$ & $71 \pm 13$ & 0.508 \\
\hline $\mathrm{pH}$ & $7.43 \pm 0.03$ & $7.42 \pm 0.09$ & 0.355 \\
\hline $\mathrm{PaO}_{2}(\mathrm{mmHg})$ & $62 \pm 15$ & $69 \pm 26$ & 0.329 \\
\hline $\mathrm{PaCO}_{2}(\mathrm{mmHg})$ & $32 \pm 6$ & $33 \pm 9$ & 0.354 \\
\hline $\mathrm{SaO}_{2} \%$ & $89 \pm 07$ & $89 \pm 10$ & 0.960 \\
\hline PAB $\left(\mathrm{cmH}_{2} \mathrm{O}\right)$ & $46 \pm 15$ & $42 \pm 15$ & 0.178 \\
\hline D-Dimer & $8619 \pm 14041$ & $8501 \pm 13400$ & 0.951 \\
\hline CRP (mg/dl) & $5.7 \pm 4.3$ & $4.8 \pm 4.2$ & 0.267 \\
\hline Creatinine (mg/dl) & $0.92 \pm 0.27$ & $1.05 \pm 0.32$ & 0.455 \\
\hline
\end{tabular}

F/M: Female/male, $\mathrm{PaO}_{2}$ Arterial partial pressure of oxygen, $\mathrm{PaCO} 2$ : Arterial partial pressure of carbon dioxide, SaO2\%: Arterial oxygen saturation, PAB: Pulmonary arterial pressure, CRP: C-reactive protein.

The most common symptom was dyspnea. Out of 149 patients, 140 (94\%) had dyspnea. 54 patients had chest pain (36.2\%), 51 patients had leg swelling (34.2\%), 17 patients had altered state of consciousness (11.4\%), 16 patients had syncope $(10.7 \%)$ and 6 patients had haemoptysis (4\%). The most commonly detected risk for pulmonary thromboembolism was immobility for more than 3 days with 47 cases (31.5\%). Cancer was prevalent in 22 cases (14.7\%).
Table 2 shows the comparison of elder group and younger group in terms of symptoms, risk factors, right ventricular dysfunction and mortality. The prevalence of chest pain was significantly higher in the patients younger group than elder group. Out of 113 patients, 34 (30\%) had chest pain. Out of 36 patients younger group, 20 (56\%) had chest pain. 
Table 2. Comparison of patients in terms of symptoms, risk factors, right ventricular dysfunction and mortality.

\begin{tabular}{|c|c|c|c|c|}
\hline & $\begin{array}{l}\text { All patients } \\
\quad(n=149)\end{array}$ & $\begin{array}{r}\text { Younger group } \\
(n=36)\end{array}$ & $\begin{array}{r}\text { Elder group } \\
\qquad(n=113)\end{array}$ & $\mathrm{p}$ \\
\hline \multicolumn{5}{|l|}{ Symptoms } \\
\hline Chest pain & $54(36.2 \%)$ & $20(56 \%)$ & $34(30 \%)$ & 0.004 \\
\hline Dyspnea & 140 (94\%) & 35 (97\%) & 105 (93\%) & 0.345 \\
\hline Hemoptysis & $6(4 \%)$ & $2(6 \%)$ & $4(4 \%)$ & 0.592 \\
\hline Syncope & $16(10.7 \%)$ & $3(8 \%)$ & $13(12 \%)$ & 0.593 \\
\hline Altered state of consciousness & $17(11.4 \%)$ & $-(-)$ & $17(15 \%)$ & 0.013 \\
\hline Leg swelling & $51(34.2 \%)$ & 14 (39\%) & 37 (33\%) & 0.765 \\
\hline \multicolumn{5}{|l|}{ Risk Factors } \\
\hline Cancer & $22(14.7 \%)$ & $7(19 \%)$ & $15(13 \%)$ & 0.363 \\
\hline Immobility for more than 3 days & 47 (31.5\%) & $3(8 \%)$ & $44(39 \%)$ & 0.001 \\
\hline Surgery in the last 1 month & $9(6 \%)$ & $2(6 \%)$ & $7(6 \%)$ & 0.889 \\
\hline Previous DVT/PTE & $15(10 \%)$ & $3(8 \%)$ & $12(11 \%)$ & 0.691 \\
\hline Chronic heart and/or pulmonary disease & $23(15.4 \%)$ & $4(12 \%)$ & 19 (17\%) & 0.409 \\
\hline Others & $5(3.4 \%)$ & $2(6 \%)$ & $5(4 \%)$ & 0.614 \\
\hline Undetected Etiology & $26(17.4 \%)$ & $15(41 \%)$ & $11(10 \%)$ & $<0.001$ \\
\hline Positive DVT & $64(43 \%)$ & $18(50 \%)$ & $46(41 \%)$ & 0.327 \\
\hline Right Ventricular Dysfunction & $66(44 \%)$ & $8(22 \%)$ & $58(51 \%)$ & 0.002 \\
\hline 30-Day Mortality & $10(6.7 \%)$ & $3(8.3 \%)$ & $7(6.2 \%)$ & 0.665 \\
\hline
\end{tabular}

The difference between two groups was statistically significant $(p=0.004)$. Besides, no change in consciousness was observed in 36 patients younger group, while altered state of consciousness was observed in 17 (15\%) of 113 patients elder group. The difference between two groups was statistically significant ( $p=0.013$ ). As a risk factor, immobilization for more than 3 days was significantly prevalent in the elder patients. Immobilization was prevalent in 44 of 113 patients (39\%) elder group and 3 of 36 patients (8\%) younger group. There was a statistically significance difference between two groups ( $p=0.001)$. Moreover, the prevalence rate of right ventricular dysfunction detected through echocardiography was found to be significantly higher is the patients elder group compared to the patients younger group (51\% vs $22 \%, p=0.002$ ). Although there was higher rate of cardiovascular comorbidity in older group than that of younger group, it was not statistically significant. Chart 1 shows the comparison of two groups in terms of the important symptoms, risk factors and prognostic factors. 


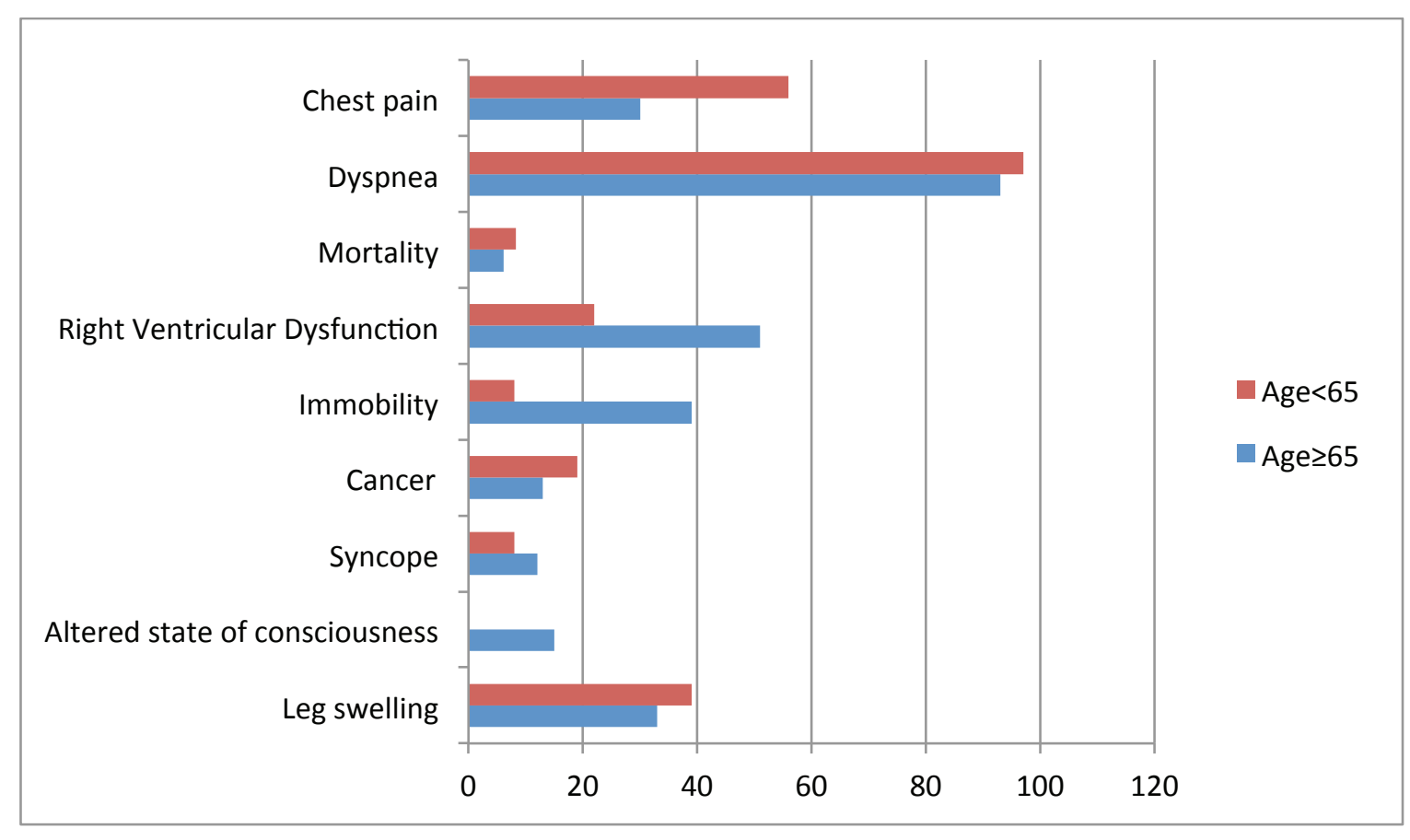

Figure 1. Comparison of the prevalence rates of symptoms, risk factors and prognostic factors in patients younger group (Age $<65$ ) and elder group (Age 265 ).

\section{DISCUSSION}

Although the symptoms of PTE are non-specific, dyspnea can be said to be the most common symptom. In this study, the most common symptom was found to be dyspnea with a prevalence rate of $94 \%$. The high prevalence rate continues with age. Chest pain was the second most common symptom with a prevalence rate of $36.2 \%$. Miniati $M$ et al. (7) carried out a prospective study with 800 patients diagnosed with PTE and found dyspnea as the most common symptom (81\%) and chest pain as the second most common symptom. Similarly, Ji QY et al. (8) found dyspnea as the most frequent symptom (64\%) and chest pain as the second most frequent symptom (45\%). In this study, the patients were divided into two groups as elder group and younger group. The prevalence of chest pain was significantly higher in the patients younger than those elderly. The prevalence of chest pain was found to be $30 \%$ in patients elder group and $56 \%$ in the patients younger group. The prevalence of chest pain decreases with age, making it more difficult to diagnose PTE. In their study, Tisserang $G$ et al. (9) divided the patients into two as patients under 75 years and patients over 75 years. They reported that the prevalence of chest pain was significantly lower in the patients over 75 compared to the patients under 75 (36\% vs 7\%). Similarly, Tomas A. et al. found that the prevalence of chest pain was significantly lower in the patients over 65 compared to the patients under 65 (10). Chest pain generally occurs in peripheral embolies, pleural irritations and in its inflammations. Lesser rate of chest pain observed in the elder patients is that since visceral pleura has less sensitive than that of younger subjects. In addition, with age, perception of pain 
also decreases which explains lesser rate of chest pain in elderly subjects. In this study, the prevalence rate of altered state of consciousness was found to be $11.4 \%$. This emerged as an issue that was not reported in the previous studies. Interestingly, altered state of consciousness was not observed in the patients younger, while its prevalence was found to be $15 \%$ in the patients elder. The risk of getting hospitalized increases with ageing due to clinical entities such as dementia and cerebrovascular diseases. In our study cerebrovascular diseases rate was $1.76 \%$ in elder group. Patients with serious clinical manifestations like PTE may also develop altered state of consciousness such as drowsiness, discomfort and agitation. These symptoms can be associated with the primary disease of a patient, thus resulting in delayed or no diagnosis of embolism. Hereditary and/or acquired risk factors play an important role in the development of pulmonary thromboembolism. In this study, the most commonly detected risk for was found to be immobility for more than 3 days (31.5\%). The second most frequently observed risk factor was chronic cardiac and/or pulmonary diseases with a ratio of $15.4 \%$, followed by cancer with a ratio of 14.7\%. A recent study by Bakabe A. et al. reported immobilization as the most common risk factor with a ratio of $43 \%(11,12)$. Husain SJ. et al. reported bedrest and immobilization as the most common risk factors for PTE with a ratio of $73 \%$. Their findings are in conformity with those obtained in this study. Age-related diseases cause immobilization which is the most important risk factor for PTE.

Findings of right ventricular dysfunction detected in echocardiography $(\mathrm{ECHO})$ are seen in approximately $40 \%$ of pulmonary embolus cases. However, accompanying cardiovascular comorbid conditions in elderly patients reduce the diagnostic value. In $\mathrm{ECHO}$, the presence of one or more of the findings of right ventricular hypokinesis or akinesia, right ventricular dilatation, interventricular septal paradoxical movement, or pulmonary hypertension reflects the finding of right ventricular dysfunction (4).

One of the important findings of this study is that right ventricular dysfunction is more common in older patients. The prevalence rate of right ventricular dysfunction was found to be $51 \%$ in the patients elder group and above and $22 \%$ in the patients young group. However, the difference between the prevalence rates did not affect prognosis. Moreover, 1-month mortality was found to be similar in both groups $(8.3 \%$ in the patients younger group and $6.2 \%$ in the patients elder group). The findings about the mortality rate can be said to be in conformity with the findings of other studies (11).

This study revealed that there are significant differences in terms of symptoms, risk factors and echocardiographic findings between the elder and younger patients with PTE.

In conclusion, PTE is observed more frequently in persons of advanced age and its clinical manifestation changes with age, making it difficult to establish an accurate diagnosis. Especially in patients aged 65 and over, chest pain loses its significance, while unexpected symptoms such as altered state of consciousness can be observed. Immobilization is an important risk factor that should be taken into account and is expected to gain more importance.

\section{Limitations and strengths}

The most important limiting factor in this study is being retrospective. We could not comment because some of the data could not be obtained from the records. Its superiority is since all the cases included in this study were identified with the BTPA angio and the possibility of misdiagnosis was eliminated. 


\section{REFERENCES}

1. White RH. The epidemiology of venous thromboembolism. Circulation 2003 Jun 17;107 (23 Suppl 1): 14-8. Review. (PMID:12814979).

2. Hoffmann B, Gross CR, Jöckel KH, Kröger K. Trends in mortality of pulmonary embolism--an international comparison Thromb Res 2010 Apr;125(4):303-8. (PMID:19635628).

3. Lilienfeld DE, Chan E, Ehland J, Godbold JH, Landrigan PJ, Marsh G. Mortality from pulmonary embolism in the United States: 1962 to 1984 . Chest 1990 Nov;98(5):1067-72. (PMID:2225945).

4. Goldhaber SZ, Visani L, De Rosa M. Acute pulmonary embolism: clinical outcomesin the International Cooperative Pulmonary Embolism Registry (ICOPER). Lancet 1999 Apr 24;353(9162):1386-9. (PMID:10227218).

5. Righini M, Goehring C, Bounameaux H, Perrier A. Effects of age on the performance of common diagnostic tests for pulmonary embolism. Am J Med 2000 Oct1;109(5):357-61. (PMID:11020391).

6. Gal G, Righini M, Roy PM, et al. Differential value of risk factors and clinical signs for diagnosing pulmonary embolism according to age. J Thromb Haemost 2005 Nov;3(11):2457-64. (PMID:16241944).
7. Miniati M, Cenci C, Monti S, Poli D. Clinical presentation of acute pulmonary embolism: survey of 800 cases. PLoS One 2012;7(2):e30891. (PMID:22383978).

8. Ji QY, Wang MF, Su CM, et al. Clinical symptoms and related risk factors in pulmonary embolism patients and cluster analysis based on these symptoms. Sci Rep 2017 Nov 2;7(1):14887. (PMID:29097743).

9. Tisserand G, Gil H, Méaux-Ruault N, Magy-Bertrand $N$. [Clinical features of pulmonary embolism in elderly: a comparative study of 64 patients]. Rev Med Interne 2014 Jun;35(6):353-6. (PMID:23968563).

10. Ramos A, Murillas J, Mascías C, Carretero B, Portero $\mathrm{JL}$. Influence of age on clinical presentation of acute pulmonary embolism. Arch Gerontol Geriatr 2000 Jun 1;30(3):189-98. (PMID:10867163).

11. Bakebe A, Kashongwe I, Mulenga C, et al. Pulmonary embolism: epidemiological data and diagnosis in Kinshasa hospitals. Int J Tuberc Lung Dis 2017 Aug 1;21(8):875-9. (PMID:28786795).

12. Husain $S J$, Zubairi $A B$, Fatima $K$, Irfan $M$, Atif $M$, Saeed MA. Clinical characteristics, management and outcome of major pulmonary embolism: an experience from a tertiary care center in Pakistan. J Pak Med Assoc 2009 Jun;59(6):372-5. (PMID:19534371). 